\title{
Self-incompatibility in plums (Prunus salicina Lindl., Prunus cerasifera Ehrh. and Prunus domestica L.). A minireview
}

\author{
Hegedüs, A. ${ }^{1}$ \& Halász, J. ${ }^{2}$ \\ ${ }^{I}$ Corvinus University of Budapest, Faculty of Food Science, Department of Applied Chemistry, \\ 1118 Budapest, Villányi út 29., Hungary. E-mail: hegedus.attila@uni-corvinus.hu; \\ ${ }^{2}$ Corvinus University of Budapest, Faculty of Horticultural Science, Department of Genetics and Plant Breeding, \\ 1118 Budapest, Ménesi út 44., Hungary
}

\begin{abstract}
Summary: Japanese plums ( $P$. salicina) and cherry plums $(P$. cerasifera) are diploid species, while European plum $(P$. domestica) cultivars are hexaploids. Most diploid species are self-incompatible while fertility relations of the hexaploid European plums are variable between selfincompatibility and self-compatibility. About twenty $S$-alleles and six inter-incompatibility groups and one $S$-haplotype responsible for the self-fruitful phenotype were described in Japanese plum cultivars, but studies on cherry plums and even on the European plum cultivars are severely restricted. This review is focused on the available information obtained from myrobalans and European plums; and discusses recent hypotheses regarding the putative origin of the hexaploid plums, and thereby indicates the possibility of allele flow between different plum species.
\end{abstract}

Key words :incompatibility group, plums, Prunus spp., self-incompatibility, $S$-genotype

Plums may have been the first species among all the fruits to attract human interest (Faust \& Surányi, 1999). In 2005 world production of plums reached a level of 9,843,398 Mt (Faostat, 2005). Cultivars of the common European plum (Prunus domestica) are used for processing and fresh market purposes in Europe while cultivars derived from the Japanesetype plum ( $P$. salicina) are the major fresh market plums sold in the USA (Okie \& Weinberger, 1996). Cherry plum ( $P$. cerasifera) is widely used as plum rootstock but its sweet, juicy fruits are also consumed fresh or dried (Pedryc, 1990). Plums belong to the genus Prunus of the family Rosaceae and thereby all species show gametophytic self-incompatibility system. Diploid plum species (Japanese plum, cherry plum) are essentially self-incompatible, self-compatibility is an exceptional phenomenon among them (Szabo, 2003). Fertility relations of the hexaploid European cultivars are variable between self-incompatibility and self-compatibility.

\section{Japanese plum (Prunus salicina Lindl.)}

Most commercial cultivars of Japanese plums are selfincompatible. The first $S$-genotype description of a Japanese plum cultivar was $S_{\mathrm{a}} S_{\mathrm{b}}$ for 'Sordum' (Yamane et al., 1999). Верри et al. (2002) demonstrated the diversity of $S$-haplotypes in Japanese plum by molecular cloning of genomic DNAs and cDNAs that encode $S$-RNases. They obtained 9 different $S$-alleles $\left(S_{\mathrm{a}}-S_{\mathrm{i}}\right)$ from 17 cultivars which presented 11 different $S$-haplotypes (Table 1 ). They found that $S$-RNase genes of Japanese plum also contained two introns at the same sites as those of sweet cherry. Selfcompatible cultivars, 'Santa Rosa', 'Late Santa Rosa' and 'Beauty' have common $S$-genotype $\left(S_{\mathrm{c}} S_{\mathrm{e}}\right)$. Since selfincompatible cultivars such as 'Oishiwasesumomo' and 'Taiyo' possess $S_{\mathrm{c}}$-haplotype, the $S_{\mathrm{e}}$-haplotype seems to be responsible for the self-compatibility trait. The self pollen tube of 'Rio' $\left(S_{\mathrm{a}} \mathrm{S}_{\mathrm{e}}\right)$ reached the micropyle, so this result further supports the involvement of $S_{\mathrm{e}}$-haplotype in selfcompatibility. In self- and cross-pollination experiments between cultivars with the $S_{\mathrm{c}} S_{\mathrm{e}}$ genotype, the resultant progenies segregated into two $S$-genotypes, $S_{\mathrm{c}} S_{\mathrm{e}}$ and $S_{\mathrm{e}} S_{\mathrm{e}}$ (Beppu et al., 2005), suggesting that only the $S_{\mathrm{e}}$-haplotype was inherited in progeny from the male parent. These results further confirmed that the $S_{\mathrm{e}}$-haplotype is responsible for self-compatibility. Expression analyses carried out by RTPCR showed that the $S_{\mathrm{e}}$-RNase gene was transcribed in the style. Therefore, it appeared that neither a deletion of the $S$ RNase gene, nor prevention of transcription of the $S$-RNase gene was the cause of self-compatibility in the $S_{\mathrm{e}}$-haplotype. This $S$-RNase allele, however, seems to be a useful marker for the self-compatible phenotype in Japanese plum. A primer, PS-Se-F (5'-ACCAACTGTAAAGTTCGAAC-3') can be successfully used in combination with the Pru-C4R primer for this purpose. 
Table I S-haplotypes and predicted inter-incompatibility groups of Japanese plum cultivars

\begin{tabular}{|c|c|c|c|c|c|}
\hline Cultivar & $S$-genotype & Reference & Cultivar & $S$-genotype & Reference \\
\hline 8 & Self-compatible & & \multicolumn{3}{|c|}{ Group V } \\
\hline Beauty & $S_{\mathrm{c}} S_{\mathrm{e}}$ & (1) & Queen Anne & $S_{\mathrm{b}} S_{\mathrm{h}}$ & (1) \\
\hline Late Santa Rosa & $S_{\mathrm{c}} S_{\mathrm{e}}$ & (1) & Yonemomo & $S_{\mathrm{b}} S_{\mathrm{h}}$ & (1) \\
\hline Santa Rosa & $S_{\mathrm{c}} S_{\mathrm{e}}$ & (1) & Group VI & & \\
\hline Rio & $S_{\mathrm{a}} S_{\mathrm{e}}$ & (1) & Bakemonosumomo & $S_{\mathrm{b}} S_{\mathrm{i}}$ & (1) \\
\hline Simka & $S_{\mathrm{e}} S_{\mathrm{k}}$ & (2) & Kasahara Hatankyou & $s_{\mathrm{b}} S_{\mathrm{i}}$ & (2) \\
\hline \multicolumn{3}{|c|}{ Group I } & \multicolumn{3}{|c|}{ Unique genotypes } \\
\hline Abandancia & $S_{\mathrm{f}} S_{\mathrm{h}}$ & (2) & Bonnie & $S_{\mathrm{g}} S_{\mathrm{h}}$ & (2) \\
\hline Kelsey & $S_{\mathrm{f}} S_{\mathrm{h}}$ & (1) & Botan & $S_{\mathrm{a}} S_{\mathrm{m}}$ & (2) \\
\hline Kelsey Paulista & $S_{\mathrm{f}} S_{\mathrm{h}}$ & (2) & Combination & $S_{\mathrm{g}} S_{\mathrm{I}}$ & (2) \\
\hline \multicolumn{3}{|c|}{ Group II } & Formosa & $S_{\mathrm{b}} S_{\mathrm{d}}$ & (1) \\
\hline Laroda & $S_{\mathrm{b}} S_{\mathrm{c}}$ & (1) & Harypickstone & $S_{\mathrm{b}} S_{\mathrm{k}}$ & (2) \\
\hline Oishinakata & $S_{\mathrm{b}} S_{\mathrm{c}}$ & (1) & Honey Rosa & $S_{\mathrm{b}} S_{\mathrm{g}}$ & (2) \\
\hline Taiyo & $S_{\mathrm{b}} S_{\mathrm{c}}$ & (1) & Lantz & $S_{\mathrm{b}} S_{1}$ & (2) \\
\hline \multicolumn{3}{|c|}{ Group III } & Oishiwasesumomo & $S_{\mathrm{c}} S_{\mathrm{d}}$ & (1) \\
\hline Burmosa & $S_{\mathrm{a}} S_{\mathrm{b}}$ & (2) & Queen Rosa & $S_{\mathrm{c}} S_{\mathrm{h}}$ & (2) \\
\hline Red Beaut & $S_{\mathrm{a}} S_{\mathrm{b}}$ & (1) & Royal-Zee & $S_{4} S_{5}$ & (3) \\
\hline Sordum & $S_{\mathrm{a}} S_{\mathrm{b}}$ & (4) & Starkgold & $S_{\mathrm{g}} S_{\mathrm{k}}$ & (2) \\
\hline \multicolumn{3}{|c|}{ Group IV } & Summer Queen & $S_{\mathrm{c}} S_{\mathrm{f}}$ & (2) \\
\hline \multirow{5}{*}{$\begin{array}{l}\text { Frontier } \\
\text { Gran Colle } \\
\text { Verna Delicious }\end{array}$} & \multirow{5}{*}{$\begin{array}{l}S_{\mathrm{b}} S_{\mathrm{f}} \\
S_{\mathrm{b}} S_{\mathrm{f}} \\
S_{\mathrm{b}} S_{\mathrm{f}}\end{array}$} & \multirow{5}{*}{$\begin{array}{l}(2) \\
(2) \\
(2)\end{array}$} & Tecumseh & $S_{\mathrm{f}} S_{\mathrm{j}}$ & (2) \\
\hline & & & Terada & $S_{\mathrm{a}} S_{\mathrm{f}}$ & (1) \\
\hline & & & White plum & $S_{\mathrm{f}} S_{\mathrm{g}}$ & (1) \\
\hline & & & Wickson & $S_{3} S_{6}$ & (3) \\
\hline & & & Royal Zee & $S_{4} S_{5}$ & (3) \\
\hline
\end{tabular}

(1) Beppu et al. (2002); (2) Beppu et al. (2003): (3) Sapir et al. (2004); (4) Yamane et al. (1999)

Five additional $S$-RNase genes corresponding to $S_{\mathrm{j}}-S_{\mathrm{n}^{-}}$ haplotypes were also identified by PCR (Верpu et al., 2003). Thirteen new $S$-genotypes were found in nineteen cultivars (Table 1). Cross-pollination and pollen tube growth tests revealed that pollen tubes were arrested in the upper middle part of stylar tissue in the crosses between the selfincompatible cultivars with the same $S$-genotypes.

An Israeli research team cloned five $S$-alleles from three commercially important Japanese plum cultivars (Sapir et al., 2004). Four of the five clones turned out to be new alleles $\left(S_{3}, S_{4}, S_{5}\right.$ and $\left.S_{6}\right)$. The fifth allele, $S_{1}$ from 'Red Beaut' corresponds to the $S_{\mathrm{a}}$-allele.

Table 1 shows the existence of six inter-incompatibility groups according to the currently available molecular data. However, further groups and/or genotypes within certain groups are presumed to be extended in the near future. For example, fruit set studies revealed that cvs. 'Methley' and 'Shiro' were cross-incompatible (Nyéki \& Szabó, 1995). Their molecular analysis may confirm their mutual incompatibility. The nature of self-compatibility is not fully described at the moment and nothing is known about the pollen expressed F-box gene in Prunus salicina.

However, we must mention that modern cultivars of Japanese plums were developed in the USA by Luther Burbank about 100 years ago, who intercrossed plums of Chinese origins ( $P$. salicina and $P$. simonii) with American native plums of several origins ( $P$. americana and $P$. munsoniana) and plums of Eurasian origins ( $P$. cerasifera)
(Ahmad et al., 2004). Cultivars released by the famous botanist and plant breeder, L. Burbank, almost all multispecies hybrids (Byrne, 1989), which suggests that their $S$-allele pool is composed as a mixture of alleles from several more or less related plum species.

\section{Myrobalan (Prunus cerasifera Ehrh.)}

First study regarding the molecular genetics of selfincompatibility in plums was published by Sutherland et al. (2004b). Since myrobalan is a diploid species, which though of little interest as a fruit crop, may serve as a simpler model for elucidating some aspects of self-incompatibility in plums. Five $S$-RNases were isolated from four myrobalan accessions. Consensus primers flanking the second intron (Sutherland et al., 2004a) amplified 1 or 2 bands in each tested diploid myrobalan accession ranging from 0.7 to $3 \mathrm{~kb}$ in size. Sequencing enabled to design allele-specific primers specific to $24 S$-alleles; full $S$-genotypes were determined for 23 myrobalans.

\section{European plum (Prunus domestica L.)}

Domestic plum is an important hexaploid fruit crop. Publications regarding its compatibility characteristics are very restricted. Initial investigations have dealt primarily 
with the economic phase of sterility, and showed that in Prunus domestica only about one half of the cultivars are self-sterile (Peters, 1916; Sutton, 1918). As most diploid plums are self-incompatible (see beforehand), the relatively rare occurrence of incompatibility in European plums is due to its hexaploid $(2 \mathrm{n}=6 \mathrm{x}=48)$ genome (Crane \& Lawrence, 1929). Since self-incompatibility is so general in the plum, cross-pollination is essential in most of the cultivars. Pollinizers must bloom at the same time as the cultivar to be pollinated, and although differences were observed in the effectiveness of pollinizers, the inter-incompatibility was not found to be extensive at the beginning of the $20^{\text {th }}$ century (Dorsey, 1919). One of the first reciprocally incompatible combinations was described by Sutton (1918), but later, several cultivars with cross- and reciprocal incompatibility were identified (Crane, 1925; Tehrani, 1991). The early controlled self- and cross-pollination experiments described cultivars as fully self-compatible, partially self-compatible and self-incompatible (Rawes, 1921). It was recorded that during the so-called second drop occurring two weeks or so after bloom, flowers with unfertilized egg cells were lost (Waugh, 1899). Unsuccessful fertilization was attributed to the unfavourable weather conditions, flower morphology etc. (Dorsey, 1919). Sterility of plums may result from male sterility, incompatibility and embryo abortion. It was quite early detected that self- and cross-incompatibility is coupled with slow pollen tube growth (Dorsey, 1919).

Male sterility may also occur in some domestic plum cultivars ('Centenar', 'Pescarus', 'Tuleu gras' and 'Tuleu timpuriu'), and this further complicates the proper cultivar association (Szabó et al., 1999). Total carbohydrate content, as well as fructose and glucose contents of the pollen from male sterile European plum cultivars ('Tuleu gras' and 'Tuleu timpuriu') were much lower compared to those of other European and Japanese plums, which may indicate a

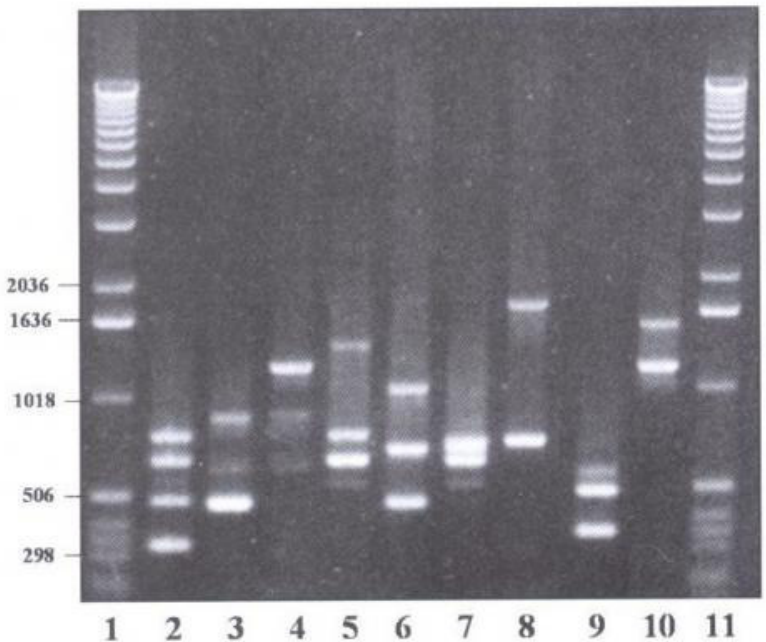

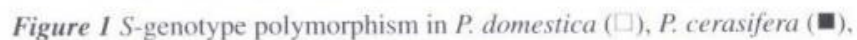
$P$. spinosa $(\bullet)$ and $P$. salicina $(\bullet)$ accessions. PCR was conducted using the EM-PC2consFD and EM-PC3consRD primer pair for the amplification of the second intron region. Tested accessions are as follows: 1. Mw marker 2. Besztercei muskotály $(\square), 3$, Obylnaia $(\mathbf{m} \times \square), 4$, Purpurovaia $(\mathbf{m} \times \square)$,

5. Ruth Gerstetter $(\square), 6$. President $(\square), 7$. Kisinovskaia rannaja ( $\square$ ),

8. P. spinosa $(\bullet)$, 9. Friar $(\bullet)$, 10. Super Giant $(\bullet)$, 11. Mw marker kind of starvation of the male sterile pollen grains (Nyéki et al., 1999).

First study regarding the molecular genetics of selfincompatibility in domestic plum was published by Sutherland et al. (2004b). In hexaploid domestic plum cultivars, a degenerate consensus primer pair amplified 2 to 4 bands ranging from 0.6 to $1.2 \mathrm{~kb}$, smaller than those of the myrobalan accessions. We have carried out a similar study (unpublished data) with the EM-PC2consFD and EMPC3consRD primer pair designed by Sutherland et al. (2004a). Our results are in accordance with the findings of Sutherland et al. (2004b): 2 to 4 bands were amplified in each cultivar and their fragment length fell between 0.6 to 1.4 kb (Figure I). Some bands with putatively identical or at least similar sizes were detected in $P$. domestica, $P$. domestica $\times P$. cerasifera hybrids, $P$. spinosa and $P$. salicina.

Sequencing enabled to design primers specific to 24 myrobalan and domestic plum $S$-alleles; and partial $S$-genotypes were determined for 19 self-incompatible domestic plum cultivars (Sutherland et al., 2004b). Phylogenetic analyses show myrobalan and plum $S$-alleles to be closely related, but no species-specific clustering can be observed among Prunus $S$-RNases, according to the pattern of trans-specific evolution (Figure 2). The Prunus and Malus $S$-RNases constitute separate clades.

According to the original hypothesis of Crane and Lawrence, the amphidiploid species Prunus domestica occurred by way of hybridization of the tetraploid $P$. spinosa L. and the diploid species $P$. arasifera Ehrh (Crane \& Lawrence, 1936). However, later it was found that all artificial amphidiploids achieved after hybridization of the two referred species differed to a considerable extent from $P$. domestica by many morphological and biological traits (Eryomine, 1991). Furthermore such amphidiploid hybrids have never appeared naturally as non-reduced gametes of stable species. Newer hypotheses were drawn as the contribution of many species to $P$. domestica genome involving $P$. cerasifera, $P$. spinosa, $P$. salicina, $P$. armeniaca, $P$. persica and $P$. microcerasus, since $P$. spinosa was deemed to be an amphidiploid hybrid of $P$. cerasifera and $P$.

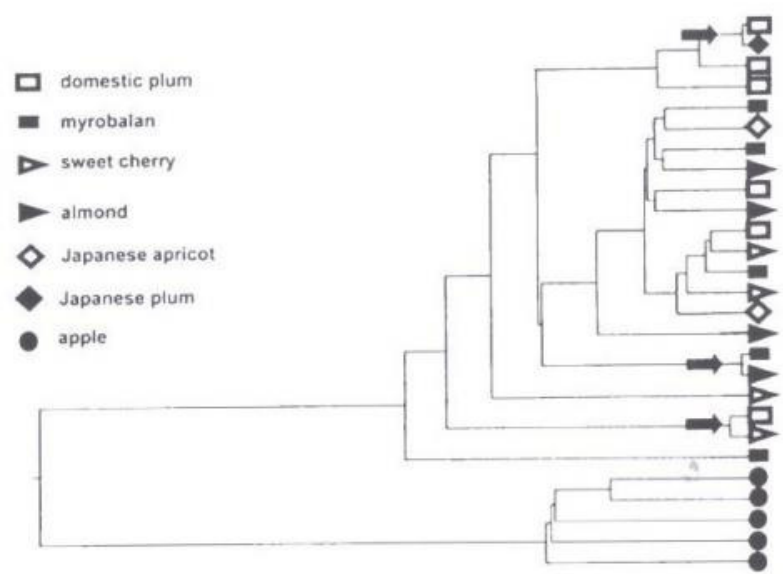

Figure 2 Dendrogram of a set of rosaceous $S$-RNase encoding DNA sequences. Plum and myrobalan $S$-alleles showing exceptional identity with other $S$-allele sequences are indicated with arrows. (After Sutherland et al., 2004b) 
microcerasus (Eryomine, 1991), while other three species contributed to the cultivated cherry plum ( $P$. cerasifera ssp. macrocarpa). Bajashvili (1991) presumed that European plum could have also originated directly from hexaploid $P$. divaricata or from $P$. spinosa (allo-ploidization). Zohary (1992) argued the allo-polyploid origin of $P$. domestica and the participation of $P$. spinosa in the formation of this species, and proposed on the basis of cytogenetic evidence that $2 x, 4 x$ or $6 x$ P. cerasifera was the sole wild stock from which the cultivated garden plum could evolve.

Variable extent of self-compatibility in many European plum cultivars may be attributed to heteroallelic pollens. In the heteroallelic pollen the $S$-alleles may interact competitively, so that the pollen is rejected in styles having any of the same $S$-alleles. In some cases it seems to be the reason for self-compatibility in the tetraploid sour cherry cultivars (Tobutt et al., 2004).

$S$-genotype analyses may also supply information regarding the origin of the species. Experiments are being carried out to get information on the extent of the allele pool and allele division between the component genomes of the domestic plum; as well as on the pollen- $S$ function.

\section{References}

Ahmad, R., Potter, D. \& Southwick, S.M. (2004): Identification and characterization of plum and pluot cultivars by microsatellite markers. J. Hortic. Sci. Biotech., 79: 164-169.

Bajashvili, E.I. (1991): Studies of some species of Prunus Mill. genus. Acta Hort., 283: 31-34.

Beppu, K., Komatsu, N., Yamane, H., Yaegaki, H., Yamaguchi, M., Tao, R. \& Kataoka, I. (2005): $S_{\mathrm{e}}$-haplotype confers selfcompatibility in Japanese plum (Prunus salicina Lindl.) J. Hortic. Sci. Biotech., 80: 760-764.

Beppu, K., Yamane, H., Yaegaki, H., Yamaguchi, M., Kataoka, I. \& Tao, R. (2002): Diversity of $S$-RNase genes and $S$-haplotypes in Japanese plum (Prumus salicina Lindl.). J. Hortic. Sci. Biotech., 77(6): 658-664.

Beppu, K., Takemoto, Y., Yamane, H., Yaegaki, H., Yamaguchi, M., Kataoka, I. \& Tao, R. (2003): Determination of $S$-haplotypes of Japanese plum (Prunus salicina Lindl.) cultivars by PCR and cross-pollination tests. J. Hortic. Sci. Biotech., 78(3): 315-318.

Byrne, D.H. (1989): Inbreeding, coancestry, and founding clones of Japanese-type plums of California and the southeastern United States. J. Amer. Soc. Hort. Sci., 114: 669-705.

Crane, M.B. (1925): Self-sterility and cross-incompatibility in plums and cherries. J. Genet., 15: 301-322.

Crane, M.B. \& Lawrence, W.J.C. (1929): Genetical and cytological aspects of incompatibility and sterility in cultivated fruits. J. Pomol. Hort. Sci., 7: 276-301.

Dorsey, M.J. (1919): A study of sterility in the plum. Genetics, 4: $417-489$.
Eryomine, G.V. (1991): New data on origin of Prumus domestica L. Acta Hort., 283: 27-29.

Faostat (2003): Agriculture data.

http://apps.fao.org/page/collections?subset = agriculture

Faust, M. \& Surányi, D. (1999): Origin and dissemination of plums. Hort. Rev., 23: 179-231.

Nyéki, J., Schmidt, J., Szabó, Z., Erdös, Z. \& Bucsek, M. (1999): Chemical analysis of the pollen of plum varieties. International Journal of Horticultural Science, 5: 25-26.

Nyéki, J. \& Szabó, Z. (1995): Cross-incompatibility in stone fruits. Horticultura Science, 28: 23-31.

Okie, W.R. \& Weinberger, J.H. (1996): Plums. In: Fruit breeding: tree and tropical fruits (Eds.: Janick, J. \& Moore, J.N.), Wiley, New York, Vol. 1. pp. 559-607.

Pedryc, A. (1990): Cseresznyeszilva (Prunus cerasifera Ehrh.) fajtáinak ès hibridjeinek értékelése. Lippay János Tudományos Ülésszak elöadásainak és posztereinek rövid összefoglalói. KEEE Kiadványai, pp. 148-149.

Peters, R.W. (1916): Pollinating fruit trees. J. Hered., 7: 365-369.

Rawes, A.N. (1921): Pollination in orchards (IV.). Self-fertility and self-sterility in plums. J. Roy. Hort. Soc., 39: 353-356.

Sapir, G., Stern, R.A., Eisikowitch, D. \& Goldway, M. (2004): Cloning of four new Japanese plum $S$-alleles and determination of the compatibility between cultivars by PCR analisis. J. Hortic. Sci. Biotech., 79(2): 223-227.

Sutherland, B.G., Robbins, T.P. \& Tobutt, K.R. (2004a): Primers amplifying a range of Prunus $S$-alleles. Plant Breed., 123: 582-584.

Sutherland, B.G., Tobutt, K.R. \& Robbins, T.P. (2004b): Molecular genetics of self-incompatibility in plums. Acta Hort., 663: $557-562$.

Sutton, I. (1918): Report on tests of self-fertility in plums, cherries and apples at the John Innes Horticultural Institution. J. Genet., 7: 281-300.

Szabó, Z. (2003): Plum (Prunus domestica L.). In: Kozma, P., Nyéki, J., Soltész, M., Szabó, Z. (Eds.): Floral Biology, Pollination and Fertilisation in Temperate Zone Fruit Species and Grape. pp. 515-522. Akadémiai Kiadó, Budapest.

Szabó, Z., Nyéki, J., Andrásfalvy, A. \& Soltész, M. (1999): Association of European plum varieties in the orchards. International Journal of Horticultural Science, 5: 21-24.

Tehrani, G. (1991): Seventy-five years of plum breeding and pollen compatibility studies in Ontario. Acta Hort., 283: 95-103.

Tobutt, K.R., Bošković, R., Cerović, R., Sonneveld, T. \& Ružić, D. (2004): Identification of incompatibility alleles in the tetraploid species sour cherry. Theor. Appl. Genet., 108: 775-785.

Waugh, F. (1899): The pollination of plums. Vermont Agric. Exp. Sta. Ann. Rep., 12: 189-209.

Yamane, H., Tao, R. \& Sugiura, A. (1999): Identification and cDNA cloning for $S$-RNases in self-incompatible Japanese plum (Prunus salicina Lindl. cv. Sordum). Plant Biotechnology, 16: 389-96.

Zohary, D. (1992): Is the European plum, Prunus domestica L., a $P$. cerasifera Ehrh. $\times$ P. spinosa L. allo-polyploid? Euphytica, 60: 75-77. 